\title{
Urgensi Revisi Undang-Undang Landas Kontinen Indonesia
}

\author{
Davina Oktivana*
}

\begin{abstract}
Abstrak
Pengaturan mengenai landas kontinen di Indonesia khususnya dalam menentukan batas terluar landas kontinen masih mengacu pada ketentuan Konvensi Jenewa tentang Landas Kontinen tahun 1958, yaitu menggunakan kriteria kedalaman dan kemampuan dalam melakukan eksploitasi. Sementara itu Indonesia telah meratifikasi Konvensi Hukum Laut 1982, yang mana kriteria dalam menentukan batas terluar landas kontinen berdasarkan konvensi ini dinilai lebih menguntungkan bagi negara pantai. Keuntungan yang dimaksud adalah penggunaan kriteria topografi dasar laut dan diperbolehkannya negara pantai mengajukan perpanjangan landas kontinen. Indonesia telah mengajukan submisi perpanjangan landas kontinen yang berlokasi di barat laut Sumatera pada tahun 2008 dan disetujui oleh Komisi Batas-Batas Landas Kontinen PBB pada tahun 2010, dan saat ini sedang mempersiapkan submisi perpanjangan landas kontinen lainnya di utara Papua dan selatan Nusa Tenggara. Adanya perkembangan dan praktik tersebut tidak diikuti dengan perubahan UU Landas Kontinen Indonesia yang seharusnya mengacu pada kriteria yang lebih relevan berdasarkan Konvensi Hukum Laut 1982. Revisi UU Landas Kontinen menjadi penting karena telah mengarah pada ketidakpastian dan pertentangan dalam hukum positif di Indonesia.
\end{abstract}

Kata kunci: landas kontinen, KHL 1982, Komisi Batas-Batas Landas Kontinen PBB, revisi undang-undang, ratifikasi.

\section{The Urgency of Indonesian Continental Shelf Act Revision}

\begin{abstract}
The definition of the outer limit of the continental shelf in Indonesian Continental Shelf Act is still referring to the 1958 Geneva Convention on the Continental Shelf, which applied the criteria of depth and the ability to exploit. On the other hand, Indonesia has ratified the 1982 Convention on the Law of the Sea, where the criteria in determining the outer limit of the continental shelf is considered more advantageous to coastal states, for instance, the application of seabed topography criteria and the admissible of coastal states to propose an extension of the continental shelf. Indonesia has submitted an extended continental shelf located in the northwest of Sumatra in 2008 and had been approved by the Commission on the Limits of the Continental Shelf of the UN in 2010. Indonesia is also currently preparing another submission located in the northern Papua and southern Nusa Tenggara. Notwithstanding the development and Indonesia's practice, these situations are not followed by adjusting the Indonesian Continental Shelf Act. Thus, the urgency of revision of
\end{abstract}

PADJADJARAN Jurnal IImu Hukum Volume 3 Nomor 2 Tahun 2016 [ISSN 2460-1543] [e-ISSN 2442-9325]

* Dosen Fakultas Hukum Universitas Padjadjaran, Jl. Dipati Ukur No. 35 Bandung, davina@unpad.ac.id, S.H., M.H., (Universitas Padjadjaran). 
Indonesia's Continental Shelf Act is necessary, due to uncertainty and contradistinction in Indonesia's positive law.

Keywords: continental shelf, 1982 UNCLOS, UN-CLCS, revision of act, ratification .

\section{A. Pendahuluan}

Landas kontinen dikenal sebagai lokasi yang kaya akan sumber daya kelautan seperti sumber daya hidrokarbon (minyak dan gas) dan sumber daya mineral serta hewan laut jenis sedenter. Eksploitasi minyak dan gas bumi (migas) di lepas pantai mulai marak dilakukan pasca berakhirnya Perang Dunia II terlebih dengan kemajuan teknologi yang memungkinkan eksplorasi dan eksploitasi di wilayah laut yang semakin dalam, serta tingginya permintaan di sektor migas. Selain migas, cadangan sumber daya mineral yang terdapat di landas kontinen diketahui kaya akan kandungan logam seperti timah, titanium, chrom, besi, tembaga, seng, perak, berlian, dan emas. Hal ini berdampak pada tingkat eksploitasi mineral di laut yang meningkat tajam. Sumber energi lainnya adalah panas bumi (thermal energy), sedenter species seperti kerang, tiram, remis, lobster dan kepiting, serta jenis ikan laut dalam yang belum banyak dieksplorasi. Bagi negara pantai khususnya negara berkembang, berbagai sumber daya kelautan yang berada di landas kontinen tersebut dapat menjadi komoditas utama yang memiliki kontribusi terhadap perekonomiannya. Dengan demikian penting untuk mengetahui dan memastikan landas kontinen ini sebab tidak menutup kemungkinan berpotensi pada sengketa laut.

Hukum internasional berperan dalam penyelesaian sengketa laut, ${ }^{1}$ termasuk peranan terkait maraknya praktik negara dalam mengeksploitasi sumber daya kelautan di landas kontinen, khususnya dalam status hukum dan delimitasi landas kontinen di antara negara yang behadapan (opposite) maupun bersebelahan (adjacent). Perkembangan pengaturan landas kontinen saat ini terdapat di dalam ketentuan Bab VI Pasal 75-85 Konvensi Hukum Laut 1982 (KHL 1982) yang mengatur batas landas kontinen selebar 200 mil laut dari garis pangkal dan memungkinkan sampai maksimal 350 mil laut dengan ketentuan harus memenuhi syarat-syarat di dalam Pasal 76 ayat 4-6. Berbeda dengan rezim Zona Ekonomi Eksklusif (ZEE), negara tidak dapat melakukan klaim sepihak (unilateral act) terhadap landas kontinen di luar 200 mil laut, tetapi harus diajukan ke komisi khusus yaitu Komisi Batas-Batas Landas Kontinen Perserikatan Bangsa-Bangsa

\footnotetext{
1 Salah satu contoh sengketa laut misalnya sengketa Laut Tiongkok Selatan. Lihat pembahasan dalam "Konflik versus Kooperasi: Upaya Penyelesaian Sengketa Laut Tiongkok Selatan dan Integrasi ASEAN ke Iklim Ekonomi Global", yang disusun oleh Garry Gumelar Pratama, Padjadjaran Jurnal Ilmu Hukum, Vol. 3, No. 1, 2016, hlm. 24 -42 .

2 Hingga tulisan ini dibuat, sebanyak 77 negara telah mengajukan perpanjangan landas kontinen di luar 200 mil laut ke Komisi Batas-batas Landas Kontinen PBB dan 26 negara telah mendapatkan rekomendasi dari komisi
} 
(PBB)/United Nations Commission on the Limits of the Continental Shelf (UN-CLCS), kemudian komisi ini akan mengeluarkan suatu rekomendasi yang sifatnya mengikat. $^{2}$

Indonesia telah memiliki undang-undang yang mengatur mengenai pemanfaatan landas kontinen, yaitu Undang-Undang Nomor 1 Tahun 1973 tentang Landas Kontinen Indonesia (UU LKI). UU LKI dikeluarkan pasca Indonesia mengeluarkan Pengumuman Pemerintah pada 17 Februari 1969 dan meratifikasi Konvensi Jenewa tentang Landas Kontinen 1958 (Konvensi LK) melalui UndangUndang Nomor 19 Tahun 1961. ${ }^{3}$ UU LKI terdiri dari 14 (empat belas) pasal yang keseluruhan isinya mengacu pada Konvensi LK.

Pengaturan mengenai batas terluar landas kontinen berdasarkan Konvensi LK menggunakan kriteria kedalaman atau sejauh kemampuan teknologi eksplorasi dan eksploitasi suatu negara di landas kontinen. Pengaturan tersebut berbeda dengan KHL 1982, yang mana negara pantai diperbolehkan untuk menentukan metode pengaturan mana yang paling menguntungkan, yaitu dua metode berdasarkan kriteria topografi dasar laut: pertama penarikan garis sepanjang 60 mil laut dari pangkal lereng kontinen, dan yang kedua, berdasarkan ketebalan sedimen.

Pasca Indonesia meratifikasi KHL 1982, UU LKI tidak pernah direvisi. Di sisi lain, Indonesia melakukan langkah besar dengan mengajukan submisi perpanjangan landas kontinen pada tahun 2008 ke Komisi Batas-Batas Landas Kontinen PBB yang kemudian mengeluarkan rekomendasi pada 17 Agustus 2010. Berdasarkan rekomendasi tersebut, Indonesia telah secara sah memiliki landas kontinen di luar 200 mil laut yang terletak di barat laut Sumatera. Rekomendasi tersebut memberikan Indonesia tambahan landas kontinen seluas $4.209 \mathrm{~km}^{2}{ }^{4}$ Selain itu, Indonesia juga telah mengeluarkan Undang-Undang Nomor 43 Tahun 2008 tentang Wilayah Negara (UU Wilayah Negara) dan Undang-Undang Nomor 32 Tahun 2014 tentang Kelautan (UU Kelautan).

tersebut, Indonesia adalah negara ke-12 yang mengajukan submisi tersebut pada tahun 2008. Perserikatan Bangsa-Bangsa (PBB), "Submissions, through the Secretary-General of the United Nations, to the Commissions on the Limits of the Continental Shelf, pursuant to article 76, paragraph 8, of the United Nations Convention on the Law of the Sea of 10 December 1982", http://www.un.org/depts/los/clcs_new/commission_ submissions.htm diakses pada 24 Oktober 2016.

$3 \quad$ Konvensi Jenewa 1958 terdiri dari 4 (empat) Konvensi, yaitu Konvensi tentang Laut Teritorial dan Zona Tambahan, Konvensi tentang Laut Lepas, Konvensi tentang Perikanan dan Konservasi Sumber Daya Hayati, dan Konvensi tentang Landas Kontinen. Indonesia hanya meratifikasi 3 (tiga) konvensi dan tidak terikat pada Konvensi tentang Laut Teritorial dan Zona Tambahan. I Wayan Parthiana, Hukum Laut Internasional dan Hukum Laut Indonesia, Bandung: Penerbit Yrama Widia, 2014, hlm. 287.

4 Sobar Sutisna dan Sora Lokita, "Indonesia First Experiences in Delineating Extended Continental Shelf to the UN-CLCS", Indonesian J. Int'I L. 682 (2010-2011), Volume 8 Number 4, Juli 2011, hIm. 690,

http://heinonline.org/HOL/LandingPage?handle=hein.journals/indjil8\&div=53\&id=\&page diakses pada 24 Oktober 2016. 
Di dalam kedua undang-undang tersebut terdapat pasal-pasal yang pengaturannya telah merujuk pada ketentuan KHL 1982. Kondisi ini memunculkan ambiguitas dan kontradiktif dalam pengaturan landas kontinen di Indonesia. Dalam kata lain, bertentangan dengan salah satu tujuan hukum, yaitu kepastian dan ketertiban hukum. Ditinjau dari asas perundang-undangan, UU LKI merupakan peraturan yang bersifat khusus, namun lahir lebih dulu. Dalam ilmu perundangundangan terdapat asas lex specialis derogate lex generalis (undang-undang yang bersifat khusus mengenyampingkan undang-undang yang bersifat umum). ${ }^{5}$ UU LKI dalam hal ini bersifat spesialis namun isinya telah ditinggalkan dengan berlakunya UU Wilayah Negara dan UU Kelautan.

Artikel ini selanjutnya akan mengungkap lebih detail mengenai fakta sejarah perkembangan pengaturan landas kontinen, tindakan pemerintah yang berkaitan dengan landas kontinen dan beberapa peraturan terkait mengenai hal ini. Kemudian di bagian akhir tulisan ini akan membahas mengenai urgensi perubahan UU LKI.

\section{B. Perkembangan Pengaturan Landas Kontinen}

\section{Sejarah Perkembangan Rezim Landas Kontinen}

Pada akhir abad ke-19, istilah 'landas kontinen' pada awalnya merupakan terminologi yang digunakan dalam konteks geologis atau geografis yang memiliki pengertian sebagai perpanjangan dasar laut mulai dari pantai hingga terdapat penurunan (lereng kontinen) sampai pada dasar laut dalam. ${ }^{6}$ Dasar laut sendiri terdiri dari tiga bagian, yakni:

1) Bagian yang tanahnya menurun secara bertahap dari titik air terendah (low water mark) ke kedalaman dengan rata-rata 130 meter, di mana sudut deklinasi meningkat tajam, wilayah ini disebut sebagai landas kontinen (continental shelf); ${ }^{7}$

2) Bagian dasar laut yang berbatasan dengan landas kontinen dan memiliki kemiringan curam dengan kedalaman semakin menurun sekitar 1.200-3.500 meter, dikenal sebagai lereng kontinen (continental slope) $;^{8}$ dan

3) Lokasi yang berbatasan dengan lereng kontinen di mana dasar laut secara bertahap semakin menurun dan terdapat ketebalan sedimen, yang disebut sebagai tanjakan kontinental (continental rise), dan berada di kedalaman sekitar 3500-5500 meter. ${ }^{9}$

5 C.S.T Kansil dan Christine S.T. Kansil, Pengantar IImu Hukum Indonesia, Jakarta: Rineka Cipta, 2014, hlm. 151.

6 Louis B. Sohn dan Kristen Gustafson, The Law of the Sea in a Nutshell, St. Paul, Minnesota: West Publishing Company, 1993, hlm. 153.

7 R.R Churchill dan A.V. Lowe, The law of the Sea, $3^{\text {rd }}$ Edition, Manchester, UK: Juris Publishing and Manchester University Press, 1999, hlm. 141.

s lbid.

$9 \quad$ Ibid. 
Ilustrasi mengenai bagian-bagian dasar laut dapat dilihat melalui gambar di bawah ini:

\section{Gambar 1. Continental Shelf Margin ${ }^{10}$}

\section{Ch. 8 THE CONTINENTAL SHELF}

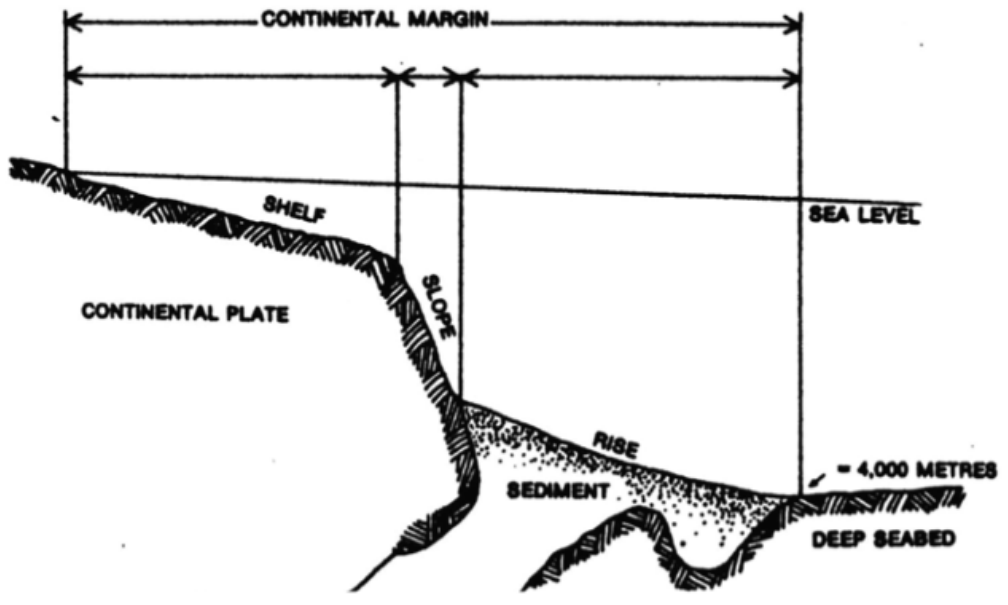

Pada awal abad ke-20 ditemukan fakta bahwa terdapat cadangan hidrokarbon yang melimpah, berbagai macam jenis hewan laut yang hidup di dasar laut (sedenter species), dan penemuan nodul-nodul yang mengandung logam berharga di dasar laut di luar 12 (dua belas) mil laut atau di luar laut teritorial. Permintaan pasar yang meningkat serta kemajuan teknologi kemudian memudahkan proses eksploitasi sumber daya kelautan di landas kontinen. Potensi sumber daya kelautan dan kegiatan eksploitasi di landas kontinen pada masa ini merupakan upaya untuk melindungi kepentingan nasional negara pantai yang bersangkutan.

Negara yang pertama mengklaim pemanfaatan dasar laut di luar laut teritorialnya (landas kontinen) adalah Amerka Serikat (AS) melalui Truman Proclamation tahun 1945. ${ }^{11}$ AS menyatakan kedalaman 200 meter (100 fathoms) sebagai batas pemanfaatan landas kontinen. ${ }^{12}$ Pasca Proklamasi Truman, muncul beberapa keberatan dari negara lain, meskipun banyak pula yang mengikuti praktik

10 Louis B. Sohn dan Kristen Gustafson, Op.cit., 1993, hlm. 156.

11 Dalam Proklamasi Truman, dinyatakan "Having concern for the urgency of conserving and prudently utulizing its natural resources, the Government of the United States regards the natural resources of the subsoil and seabed of the continental shelf beneath the high seas but contiguous to the coasts of the United States as appertaining to the United States, subject to its jurisdiction and control". Yoshifumi Tanaka, The International Law of the Sea, Cambridge: Cambridge University Press, 2012, hlm. 33.

12 Shigeru Oda, International Law of the Resources of the Sea, Netherlands: Sijthoff and Noordhoff International Publishers BV Alphen aan de Rijn, 1979, hIm. 79. 
serupa dengan dasar pemikiran apabila sudah melakukan klaim, negara dapat memiliki keuntungan dari sumber daya kelautan yang terdapat di landas kontinen, kalaupun tidak terdapat sumber daya kelautan yang dimaksud, maka negara tersebut tidak memiliki kerugian apapun. ${ }^{13}$

Pada tahun 1951, International Law Commission (ILC) mulai menyusun draft article terkait landas kontinen dan topik hukum laut internasional lainnya sebagai persiapan Konferensi Hukum Laut yang pertama pada tahun 1958. Konferensi tersebut menghasilkan 4 (empat) konvensi, salah satunya adalah Konvensi LK yang efektif berlaku pada tahun 1964. Konvensi ini memberikan pengertian dan batas landas kontinen sebagai dasar laut dan tanah dibawahnya yang berdampingan dengan pantai tetapi berada di luar laut teritorial sampai dengan kedalaman 200 meter atau sampai kedalaman yang masih masih memungkinkan dilakukannya eksploitasi sumber daya kelautan. ${ }^{14}$

Kriteria dengan formulasi kedalaman 200 meter diterapkan berdasarkan pada perhitungan jarak rata-rata di mana landas kontinen biasanya berakhir dan juga sebagai keseragaman aturan dalam konsep landas kontinen. ${ }^{15}$ Sementara kriteria 'expliotability' diterapkan agar negara pantai yang bermaksud memanfaatkan landas kontinen lebih dari 200 meter dapat terwujud ketika memiliki teknologi yang memungkinkan aktivitas eksploitasi tersebut. ${ }^{16}$

Status landas kontinen bagi negara pantai adalah hak-hak berdaulat (sovereign rights) dalam memanfaatkan sumber daya kelautan yang terdapat didalamnya. ${ }^{17}$ Negara pantai dalam melakukan kegiatan eksplorasi dan eksploitasi sumber daya kelautan memiliki hak eksklusif, sekalipun negara pantai tidak memanfaatkan landas kontinen, negara atau pihak lain yang akan memanfaatkannya harus mendapatkan izin dari negara pantai tersebut. ${ }^{18} \mathrm{Hak}$ negara pantai tersebut tidak bergantung pada pendudukan atau berbagai jenis bentuk proklamasi apapun. ${ }^{19}$ Pengaturan mengenai hal tersebut menurut Donald R. Rothwell dan Tim Stephens karena landas kontinen melekat pada negara pantai secara ipso facto, ipso jure, dan $a b$ initio seperti halnya laut teritorial, dan membatalkan klaim oleh negara pantai sebelumnya. ${ }^{20}$

Sumber daya kelautan yang dimaksud adalah sumber daya mineral dan sumber daya non-hayati lainnya di dasar laut dan tanah dibawahnya, serta organisme hidup

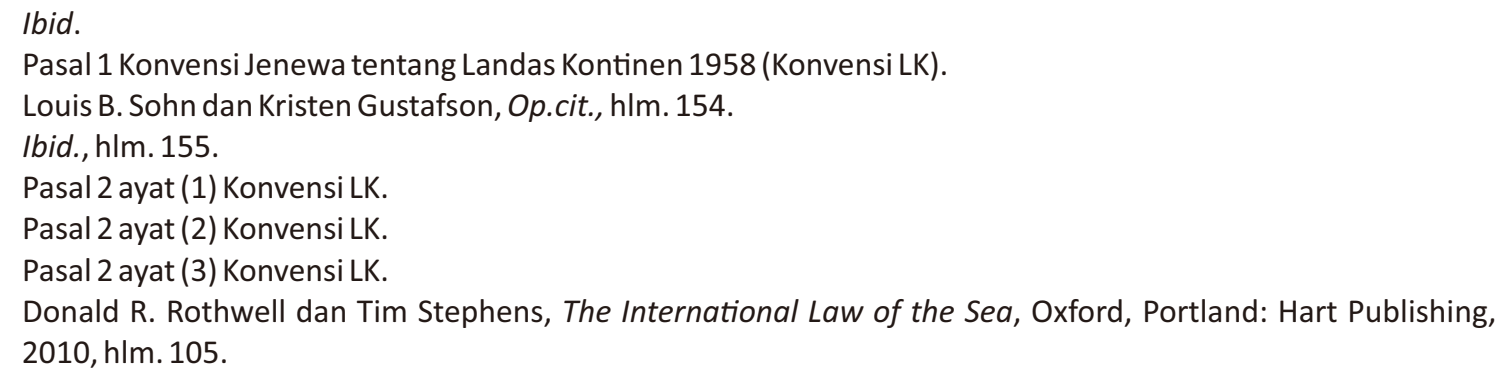


yang termasuk ke dalam sedenter species. ${ }^{21}$ Kebebasan negara pantai dalam melakukan eksplorasi dan eksploitasi di landas kontinen dapat dilakukan selama tidak mengganggu peletakan kabel dan pipa di dasar laut oleh negara lain, temasuk gangguan terhadap navigasi, penangkapan ikan, konservasi, serta riset ilmiah kelautan. ${ }^{22}$ Dalam pembangunan instalasi atau struktur bangunan lainnya, negara pantai harus menetapkan zona keamanan (safety zones) dengan jarak maksimal 500 meter di sekeliling instalasi atau struktur bangunan tersebut. ${ }^{23}$ Bagi pihakpihak yang bermaksud mengadakan riset ilmiah di landas kontinen, maka harus terlebih dahulu memperoleh izin dari negara pantai dan wajib mengumumkan hasil penelitiannya tersebut. ${ }^{24}$

Penetapan batas landas kontinen bagi 2 (dua) negara berdekatan yang pantainya berhadapan (opposite) atau bersebelahan (adjacent) harus dilakukan melalui perjanjian bilateral, dan apabila tidak terdapat perjanjian tersebut maka penetapan batas tersebut dilakukan dengan menggunakan prinsip equidistance yang menghasilkan median line dan equidistance dari titik-titik yang terdekat pada garis pangkal laut teritorial kedua negara. ${ }^{25}$ Negara pantai juga memiliki hak untuk melakukan eksploitasi di dasar laut yang berdekatan dengan pantainya dengan melakukan pembuatan terowongan (tunneling) dari daratan. ${ }^{26}$ Pendapat seorang ahli perminyakan menyatakan bahwa pembuatan terusan-terusan (terowongan) dari darat dinilai lebih ekonomis dibandingkan pengeboran dari atas permukaan air, juga dinilai lebih aman dari sudut pelayaran karena tidak terdapat gangguan navigasi. ${ }^{27}$

Pasca berlakunya Konvensi LK, perdebatan mengenai ketentuan batas landas kontinen berdasarkan Pasal 1 semakin tajam. Hal ini terjadi karena rumusan Pasal 1 tersebut merupakan hasil kompromi antara negara-negara yang mendasarkan pengertian landas kontinen secara geologis, yaitu kedalaman 200 meter (Inggris, Lebanon, Belanda, dan Perancis) dan negara-negara yang menggunakan kriteria 'exploitability' (Argentina, Korea, dan Panama). ${ }^{28}$ Konsep 'exploitability' ini dianggap tidak memadai dan tidak jelas, karena dapat menimbulkan dikuasainya sebagian besar dasar laut dan mungkin mencapai dasar samudera oleh beberapa negara, khususnya negara maju, hal ini disampaikan oleh perwakilan Malta, Arvin Pardo dalam Sidang Umum PBB tahun $1967 .{ }^{29}$

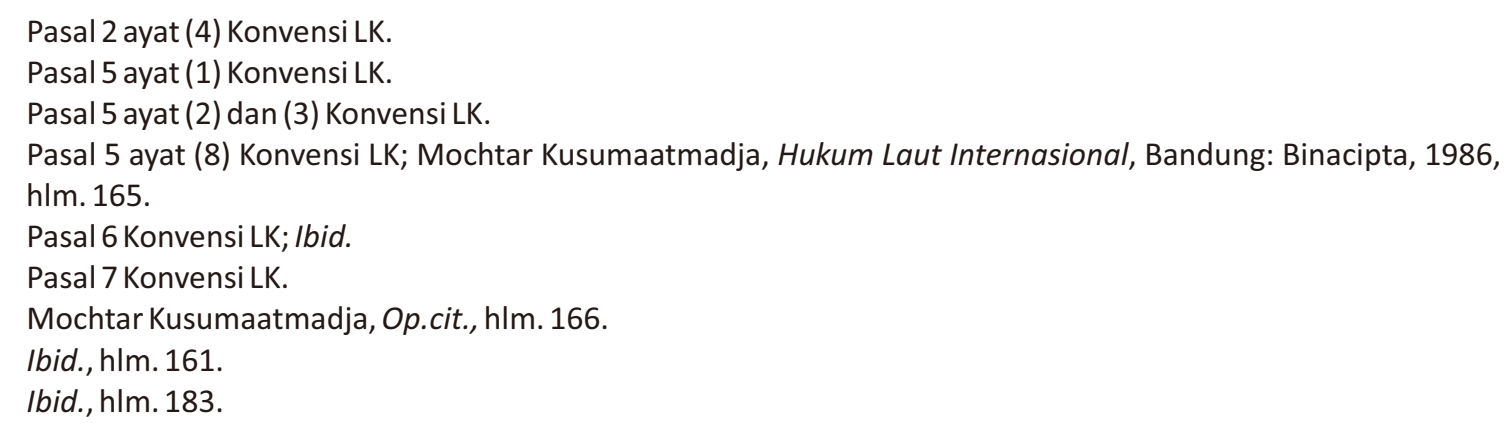


Majelis Umum PBB pada tahun 1969 menyatakan bahwa Konvensi LK tidak memberikan definisi yang cukup terkait batas di mana negara dapat melaksanakan hak-hak berdaulatnya untuk mengeksplorasi dan mengeksploitasi sumber daya alam dan ketentuan tersebut belum menjadi kebiasaan hukum internasional. ${ }^{30}$ Putusan International Court of Justice (ICJ) dalam kasus North Sea Continental Shelf menyatakan konsep landas kontinen sebagai 'natural prolongation' atau perpanjangan alamiah dari daratan suatu negara dan perpanjangan pelaksanaan hakhak berdaulat terkait kegiatan eksplorasi dan eksploitasi sumber daya alamnya, dengan kata lain, sebagai hak yang melekat. ${ }^{31}$ Saat ini konsep 'natural prolongation' menjadi dasar pengaturan dan dasar penetapan batas landas kontinen di antara negara yang berhadapan atau bersebelahan.

\section{Pengaturan Landas Kontinen Berdasarkan Konvensi Hukum Laut 1982}

Pengaturan mengenai landas kontinen terdapat di dalam ketentuan Bab VI, Pasal 76-85 KHL 1982. Kriteria bagi negara pantai dalam menentukan batas landas kontinen, yaitu mencakup daerah dasar laut dan tanah dibawahnya, sepanjang merupakan kelanjutan alamiah wilayah daratannya hingga mencapai pinggiran luar tepi kontinen; atau sejauh 200 mil laut dari garis pangkal di mana lebar laut teritorial diukur, dengan syarat pinggiran luar tepi kontinennya tidak mencapai 200 mil laut. ${ }^{32}$

Pinggiran luar tepi kontinen tersebut meliputi kelanjutan daratan negara pantai yang terdiri dari dasar laut dan tanah dibawahnya dari dataran kontinen, lereng kontinen (continental slope), dan tanjakan kontinen (continental rise). ${ }^{33}$ Pinggiran luar tepi kontinen tidak mencakup dasar samudera atau yang dikenal sebagai rezim Kawasan (the Area). Berikut adalah gambar batas landas kontinen berdasarkan Pasal 76 KHL 1982:34

\footnotetext{
Donald R. Rothwell dan Tim Stephens, Op.cit., hlm. 106.

Ibid., hlm. 107.

Pasal 76 ayat (1) Konvensi Hukum Laut 1982 (KHL 1982).

Pasal 76 ayat (3) KHL 1982.

Suparman Diraputera, (et.al.), “Naskah Akademik RUU Undang-undang No. 1 Tahun 1974 tentang Landas Kontinen Indonesia", http://www.bphn.go.id/data/documents/naskah_akademik_ruu tentang_landas kontinen_indonesia.pdf, hlm. 16, diakses pada 26 Oktober 2016.
} 
Gambar 2. Batas Landas Kontinen Berdasarkan Pasal 76 KHL 1982

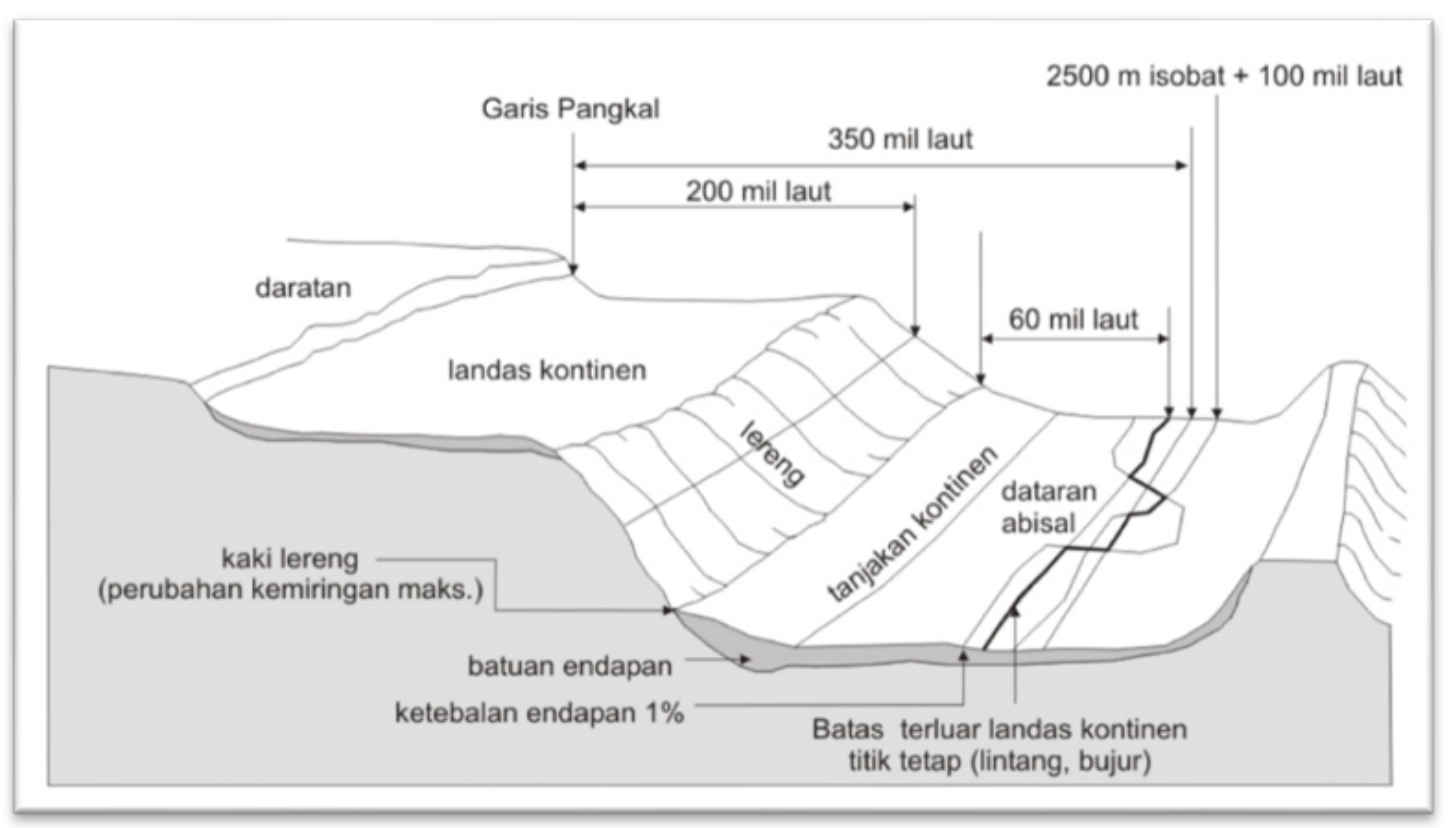

Negara pantai dapat menetapkan pinggiran luar tepi kontinen melebihi 200 mil laut dari garis pangkal dengan menarik garis lurus yang merujuk pada titik-titik tetap (fixed point) dan tidak melebihi 60 mil laut dari kaki lereng kontinen dengan ketebalan endapan (sedimentary rocks) paling sedikit 1\% dari jarak terdekat antara titik tersebut dan kaki lereng kontinen. ${ }^{35}$ Penetapan titik-titik tetap yang menjadi garis batas terluar landas kontinen tidak boleh melebihi 350 mil laut dari garis pangkal, atau tidak boleh melebihi 100 mil laut dari garis batas kedalaman (isobath) 2500 meter. $^{36}$

Apabila negara pantai berkeinginan untuk menentukan batas landas kontinen di luar 200 mil laut, maka negara tersebut harus mengajukan permohonan ke Komisi Batas-Batas Landas Kontinen PBB yang dibentuk berdasarkan Annex II. ${ }^{37}$ Rekomendasi yang dikeluarkan oleh komisi tersebut bersifat final dan mengikat. Dalam menentukan batas landas kontinen di luar 200 mil laut, Komisi Batas-Batas Landas Kontinen PBB menggunakan Scientific and Technical Guidelines of the Commission on the Limits of the Continental Shelf dan Manual on the Technical Aspects of the United Nations Convention on the Law of the Sea (TALOS).

Negara pantai memiliki hak-hak berdaulat (sovereign rights) dalam melakukan kegiatan eksplorasi dan eksploitasi secara eksklusif, artinya segala kegiatan tersebut tunduk pada peraturan perundang-undangan negara pantai. ${ }^{38}$ Hak

\footnotetext{
Pasal 76 Ayat (4) KHL 1982.

Pasal 76 ayat (5) KHL 1982.

Pasal 76 ayat (8) KHL 1982; Donald R. Rothwell dan Tim Stephens, Op.cit., hlm. 105.

Pasal 77 KHL 1982.
} 
berdaulat negara pantai atas landas kontinennya tidak tergantung pada penguasaan (occupation) maupun berbagai bentuk proklamasi lainnya. Sumber daya kelautan yang dimaksud adalah sumber daya mineral dan sumber daya nonhayati lainnya yang berada di dasar laut dan tanah dibawahnya termasuk jenis organisme hidup seperti sedenter species yang pada saat dipanen berada di dasar laut atau tanah dibawahnya, dan hanya dapat bergerak selama ada kontak fisik dengan dasar laut atau tanah dibawahnya.

Hak berdaulat negara pantai dalam kegiatan eksplorasi dan eksploitasi di landas kontinen tetap harus menghormati hak-hak negara lain terkait navigasi dan hak-hak lain yang diatur oleh KHL 1982, ${ }^{39}$ seperti hak untuk meletakkan pipa dan kabel bawah laut. ${ }^{40}$ Negara pantai memiliki hak untuk mengatur peletakan pipa dan kabel bawah laut di landas kontinennya, terkait kegiatan eksplorasi dan eksploitasi sumber daya kelautan dan tindakan pencegahan, pengaturan, dan pengurangan polusi yang berasal dari pipa tersebut. Pengaturan mengenai pembangunan pulau buatan, instalasi, atau struktur bangunan lainnya yang berada di atas landas kontinen diatur oleh Pasal 80 yang secara mutatis mutandis sama dengan ketentuan Pasal 60 yaitu pengaturan pembangunan serupa di atas yang ada di ZEE.

Terkait dengan kegiatan eksploitasi sumber daya kelautan di landas kontinen di luar 200 mil laut, terdapat ketentuan dalam Pasal 82 yang mengatur mengenai pembayaran dan bagi hasil antara negara tersebut dengan International Seabed Authority (ISBA) dimulai setelah 5 (lima) tahun pertama produksi dan dimulai pada tahun ke- 6 sebesar $1 \%$ dari hasil produksi, dan naik setiap tahunnya sebesar $1 \%$ dan akan tetap sebesar $7 \%$ setelah produksi tahun ke- $12 .{ }^{41}$ Ketentuan tersebut memiliki pengecualian terhadap negara berkembang yang menjadi pengimpor sumber daya mineral. Pembayaran tersebut diserahkan melalui Otoritas, kemudian didistribusikan ke negara-negara anggota KHL 1982 dengan dasar kriteria equitable sharing dan mempertimbangkan kepentingan dan kebutuhan bagi negara berkembang dan khususnya negara yang kurang berkembang serta negara tidak berpantai.

\section{Praktik Indonesia}

1. Undang-Undang Nomor 1 Tahun 1973 tentang Landas Kontinen Indonesia

UU LKI mengatur mengenai pengertian dan batas landas kontinen yaitu dasar laut dan tanah dibawahnya di luar perairan wilayah Republik Indonesia sebagaimana diatur dalam Undang-Undang Nomor 4 Prp Tahun 1960 tentang Perairan Indonesia

\footnotetext{
Pasal 78 ayat (2) KHL 1982.

Pasal 79 KHL 1982.

Suparman Diraputera, (et.al.), Op.cit., hlm. 17.
} 
(UU Perairan Indonesia 1960) sampai kedalaman 200 meter atau lebih, di mana masih mungkin diselenggarakan eksplorasi dan eksploitasi kekayaan alam. ${ }^{42}$ Pengertian sumber daya kelautan yang terdapat di landas kontinen merujuk pada sumber daya mineral dan sumber yang tak bernyawa lainnya di dasar laut dan/atau di dalam lapisan tanah dibawahnya dan organisme hidup yang termasuk dalam sedenter species. ${ }^{43}$ Sedangkan pengertian eksplorasi dan eksploitasi adalah usahausaha pemanfaatan kekayaan alam di landas kontinen sesuai dengan istilah yang digunakan dalam peraturan perundangan yang berlaku di bidang masing-masing. ${ }^{44}$

Status hukum di landas kontinen adalah penguasaan penuh dan hak eksklusif serta kepemilikan kekayaan alam di landas kontinen oleh Indonesia. ${ }^{45}$ Indonesia memiliki negara-negara tetangga baik berdampingan maupun berhadapan, maka berkaitan dengan hal tersebut, penetapan garis batas landas kontinen dengan negara-negara tetangga dilakukan dengan mengadakan perundingan untuk mencapai persetujuan. ${ }^{46} \mathrm{Hal}$ ini dilakukan dengan pembentukan Tim Teknis Landas Kontinen pasca ratifikasi Konvensi LK untuk merundingkan batas-batas landas kontinen dengan negara-negara tetangga, antara lain: Australia, India, Thailand, Malaysia, Vietnam, Filipina, dan Papua Nugini.

Kegiatan eksplorasi dan eksploitasi sumber-sumber kekayaan alam di landas kontinen Indonesia harus dilakukan sesuai dengan peraturan perundangan yang berlaku di bidang masing-masing. ${ }^{47}$ Kegiatan penyelidikan ilmiah dalam menemukan sumber kekayaan alam di landas kontinen (penelitian terhadap mineral, biologis, dan ekologis) harus dilakukan berdasarkan peraturan pemerintah. ${ }^{48}$ Dalam melakukan kegiatan eksplorasi dan eksploitasi sumber kekayaan alam, maka pembangunan, pemeliharaan instalasi-instalasi, kapal-kapal dan/atau alat-alat lainnya di landas kontinen dan/atau diatasnya dilindungi terhadap pihak ketiga dengan menetapkan daerah terlarang selebar 500 meter dari titik terluar pada instalasi, kapal, atau alat-alat yang dibangun di atas landas kontinen Indonesia. ${ }^{49}$ Selain itu, diatur pula melalui peraturan pemerintah mengenai penetapan suatu daerah terbatas (zona keamanan) selebar tidak melebihi 1.250 meter terhitung dari titik-titik terluar dari daerah terlarang itu, di mana kapal-kapal pihak ketiga dilarang membuang atau membongkar sauh.

Apabila terjadi pencemaran, maka pelaku kegiatan eksplorasi dan eksploitasi di landas kontinen Indonesia harus mengambil langkah-langkah terkait hal pen-

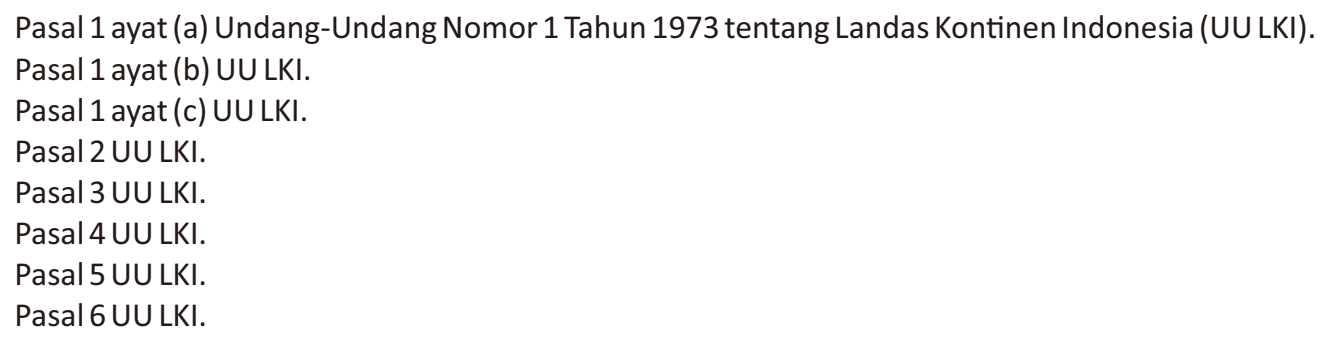


cegahan terjadinya pencemaran air laut dan udara diatasnya serta mencegah meluasnya pencemaran apabila telah terjadi pencemaran. ${ }^{50}$ Keseluruhan kegiatan eksplorasi dan eksploitasi sumber kekayaan alam di landas kontinen (pembangunan instalasi, kapal, penetapan daerah terlarang, penetapan daerah terbatas) tunduk pada ketentuan peraturan perundang-undangan Indonesia. ${ }^{51}$

Kegiatan eksplorasi dan eksploitasi kekayaan alam di landas kontinen juga harus memperhatikan dan melindungi kepentingan-kepentingan antara lain: (a) Pertahanan dan keamanan nasional; (b) Perhubungan; (c) Telekomunikasi dan transmisi listrik di bawah laut; (d) Perikanan; (e) Penyelidikan oseanografi dan penyelidikan ilmiah lainnya; dan (f) Cagar alam. ${ }^{52}$ Terakhir, pengaturan mengenai ketentuan-ketentuan pidana apabila tidak mematuhi ketentuan Pasal 4, Pasal 5, dan Pasal 8 dengan hukuman penjara selama-lamanya 6 (enam) tahun dan denda setinggi-tingginya Rp1.000.000,-(satu juta rupiah). ${ }^{53}$

\section{Pengajuan Landas Kontinen di Luar $\mathbf{2 0 0}$ mil laut oleh Indonesia}

Pengajuan landas kontinen di luar 200 mil laut harus mengikuti prosedur dan mekanisme Komisi Batas-Batas Landas Kontinen PBB. Indonesia mengajukan submisi yang berisi data-data hasil survei landas kontinen ke Komisi Batas-Batas Landas Kontinen PBB terkait landas kontinen di luar 200 mil laut yang berlokasi di barat laut Sumatera. Hasil survei landas kontinen tersebut didapatkan melalui tahapan pengumpulan data, desktop study, dan survei seismic multichannel. Tahapan pengumpulan data dalam penentuan batas terluar landas kontinen adalah sebagai berikut: ${ }^{54}$

1) Penetapan garis pangkal - berdasarkan daftar titik-titik kordinat yang terdapat di dalam Peraturan Pemerintah Republik Indonesia Nomor 38 Tahun 2002 tentang Daftar Koordinat Geografis Titik-Titik Garis Pangkal Kepulauan Indonesia (PP 38/2002);

2) Penarikan garis batas maritim - Penentuan garis ZEE sepanjang 200 mil laut dan perjanjian batas-batas maritim dengan negara lain;

3) Penentuan garis constraint (cut-off) sebagai batas maksimal yang diperbolehkan yang tidak melebihi 350 mil laut dari garis pangkal atau tidak melebihi 100 mil laut dari garis isobath 2500 meter; dan

\footnotetext{
Pasal 8 UU LKI.

Pasal 9 UU LKI.

Pasal 10 UU LKI.

Pasal 11 UU LKI.

Khafid, “Pengalaman melakukan parsial submisi Landas Kontinen Indonesia di luar 200 mil laut di sebelah barat laut Sumatera untuk mendukung penyusunan Rancangan Undang-Undang Landas Kontinen Indonesia", disampaikan dalam kegiatan Sosialisasi RUU tentang Landas Kontinen Indonesia, Selasa, 26 April 2011, Jakarta, http://ditjenpp.kemenkumham.go.id/files/doc/1276 khafid\%20\%20Pengalaman\%20Submisi\%20 LKI\%20untuk\%20mendukung\%20RUU\%20Landas\%20Kontinen.pdf, hIm. 5-6, diakses pada 20 Oktober 2016.
} 
4) Penentuan garis batas dengan penentuan kaki lereng (foot of the slope) yang didefinisikan sebagai perubahan maksimum gradien pada permukaan dasar laut, dengan cara (a) rumus jarak 600 mil laut dari kaki lereng (Hedberg Line); dan (b) ketebalan sedimen minimal 1\% (Gardiner Formula).

Tahap selanjutnya adalah desktop study, yaitu pengolahan data-data menggunakan software khusus. Data-data yang mendasari desktop study antara lain: (1) data Batimetri; (2) data ketebalan sedimen; (3) titik-titik kordinat berdasarkan PP 38/2002; (4) garis pantai; dan (5) peta ZEE. ${ }^{55}$ Tindak lanjut setelah pelaksanaan desktop study adalah survei landas kontinen, yaitu survei seismik di landas kontinen di luar 200 mil laut di sebelah barat laut Sumatera untuk melengkapi data ketebalan sedimen dalam memenuhi ketentuan Pasal 76 ayat (4)(a)(1). ${ }^{56}$

Pemerintah Indonesia mengajukan submisi parsial Landas Kontinen di luar 200 mil laut ke Komisi Batas-Batas Landas Kontinen PBB pada tanggal 16 Juni 2008. Delegasi Pemerintah Indonesia melakukan presentasi dalam sidang komisi di markas PBB, New York pada 24 Maret 2009 untuk menjelaskan argumentasi dalam daftar koordinat batas landas kontinen di luar 200 mil laut di barat laut Sumatera. Komisi Batas-Batas Landas Kontinen PBB kemudian membentuk Sub-Komisi untuk menangani submisi Indonesia dan melakukan serangkaian pertemuan dengan Pemerintah Indonesia (Delri) yang diketuai oleh Dirjen Hukum dan Perjanjian Internasional Kementerian Luar Negeri (Kemlu) dengan anggota Kepala Badan Koordinasi Survei dan Pemetaan Nasional (Bakosurtanal-sekarang bernama Badan Informasi Geospasial/BIG), Direktur Inventarisasi Teknologi Sumber Daya Alam Badan Pengkajian dan Penerapan Teknologi (BPPT), Kepala Dinas HidroOseanografi Tentara Nasional Indonesia Angkatan Laut (TNI-AL), dan Kantor Perutusan Tetap Republik Indonesia (PTRI) New York. ${ }^{57}$

Pertemuan antara Sub-Komisi dan Pemerintah Indonesia dilakukan pada 8-10 September 2009, dilanjutkan dengan pertemuan formal pada 30 Maret-1 April 2010, dan pertemuan terakhir dilaksanakan pada 12-13 Agustus $2010 .{ }^{58}$ Substansi dari rangkaian pertemuan tersebut adalah klarifikasi dan permintaan penambahan data yang dibutuhkan Sub-Komisi. Survei tambahan dilakukan oleh Indonesia pada 20 Januari-18 Februari 2010 terkait data-data seismik untuk menentukan ketebalan sedimen 1\% (Gardiner Formula) di beberapa titik koordinat.

Sidang Sub-Komisi dan Komisi Batas-Batas Landas Kontinen PBB dilakukan pada 16 Agustus 2010 dan menghasilkan rekomendasi yang disampaikan pada 17

\footnotetext{
Ibid.

Ibid.

lbid., hlm. 7.

8 Sobar Sutisna dan Sora Lokita, Op.cit., hlm. 688.
} 
Agustus 2010, menyatakan bahwa submisi Indonesia terkait landas kontinen di luar 200 mil laut di wilayah barat laut Sumatera secara resmi menjadi landas kontinen Indonesia seluas $4209 \mathrm{~km}^{2}$, lebih luas dibandingkan dengan area yang diajukan sebelumnya yaitu seluas $\pm 3500 \mathrm{~km}^{2} .{ }^{59} \mathrm{Gambar}$ di bawah ini memperlihatkan area landas kontinen Indonesia di luar 200 mil laut berdasarkan rekomendasi Komisi Batas-Batas Landas Kontinen PBB.

\section{Gambar 3. Landas Kontinen Indonesia di Barat Laut Sumatera Berdasarkan Rekomendasi Komisi Batas-Batas Landas Kontinen PBB ${ }^{60}$}

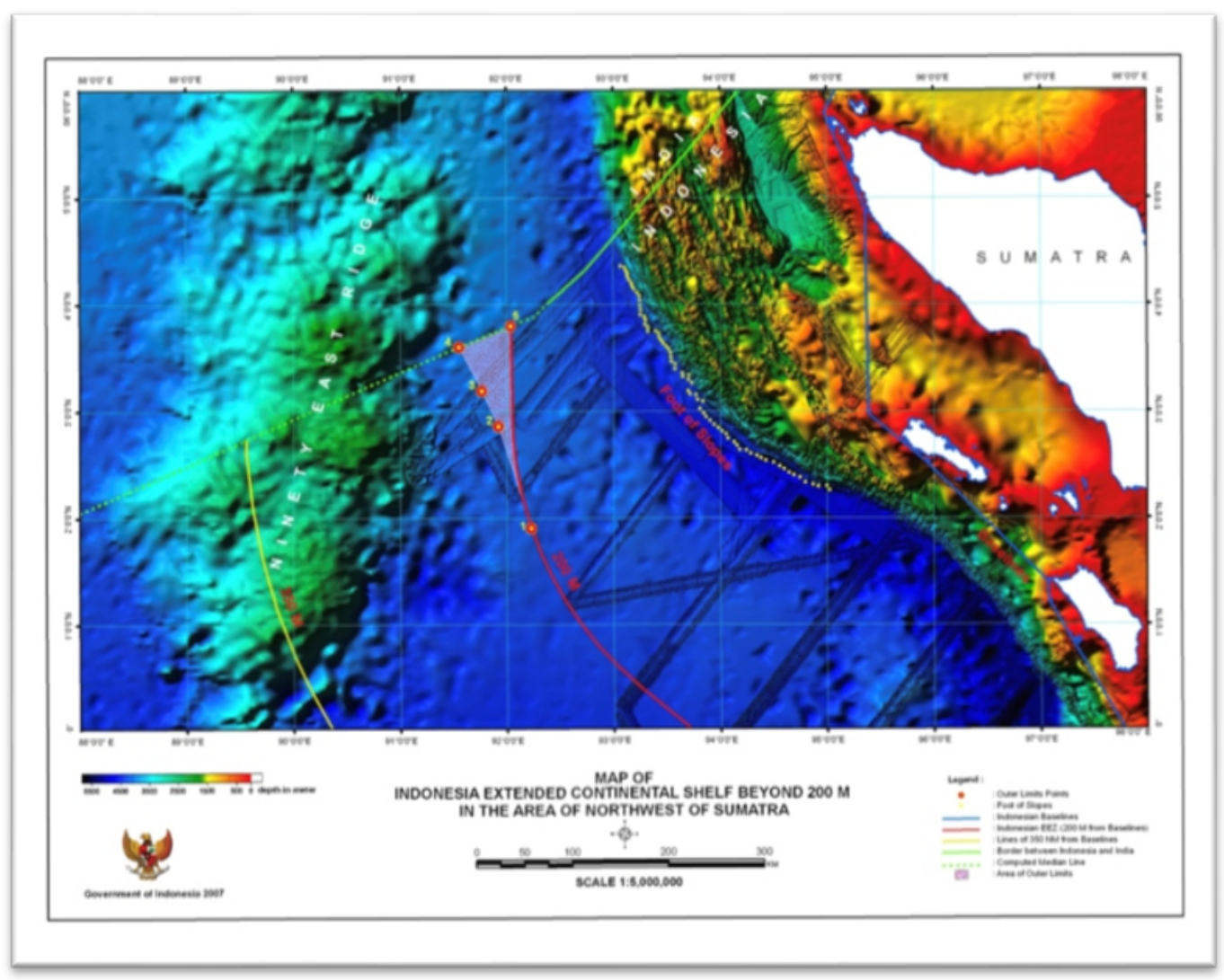

Saat ini Indonesia sedang melakukan survei landas kontinen sebagai persiapan pengajuan submisi terkait landas kontinen Indonesia di luar 200 mil laut yang berlokasi di selatan Nusa Tenggara (Pulau Sumba) dan di utara Papua. Perkembangan saat ini berdasarkan survei landas kontinen yang sedang berlangsung di selatan Sumba menunjukan variasi ketebalan sedimen antara $<1 \%$ dan

59 Ibid., hlm. 690.

60 PBB, "Summary of Recommendations of the Commission of the Limits of the Continental Shelf in regard to the submission made by Indonesia in respect of the area north west of Sumatera on 16 June 2008", http://www.un.org/depts/los/clcs new/submissions files/idn08/Summary\%20Recommendations\%20for\%2 Olndonesia.pdf, diakses pada 22 Oktober 2016. 
hingga ketebalan sedimen $1,81 \% .{ }^{61}$ Sementara untuk di utara Papua, survei landas kontinen menunjukkan ketebalan sedimen pada daerah sekitar kaki lereng adalah kurang lebih 2000 meter, dan berdasarkan pengukuran seismik, ketebalan sedimen berkisar 500 sampai 700 meter dengan di beberapa tempat terdapat cekungan yang tidak terlalu lebar dengan ketebalan sedimen berkisar 1500 meter. ${ }^{62}$ Hasil survei tersebut juga mengungkapkan terdapat potensi overlapping antara batas landas kontinen Indonesia di utara Papua dengan Papua Nugini dan Micronesia. ${ }^{63}$

\section{Gambar 4. Potensi Wilayah Landas Kontinen Indonesia di Luar 200 mil laut ${ }^{64}$}

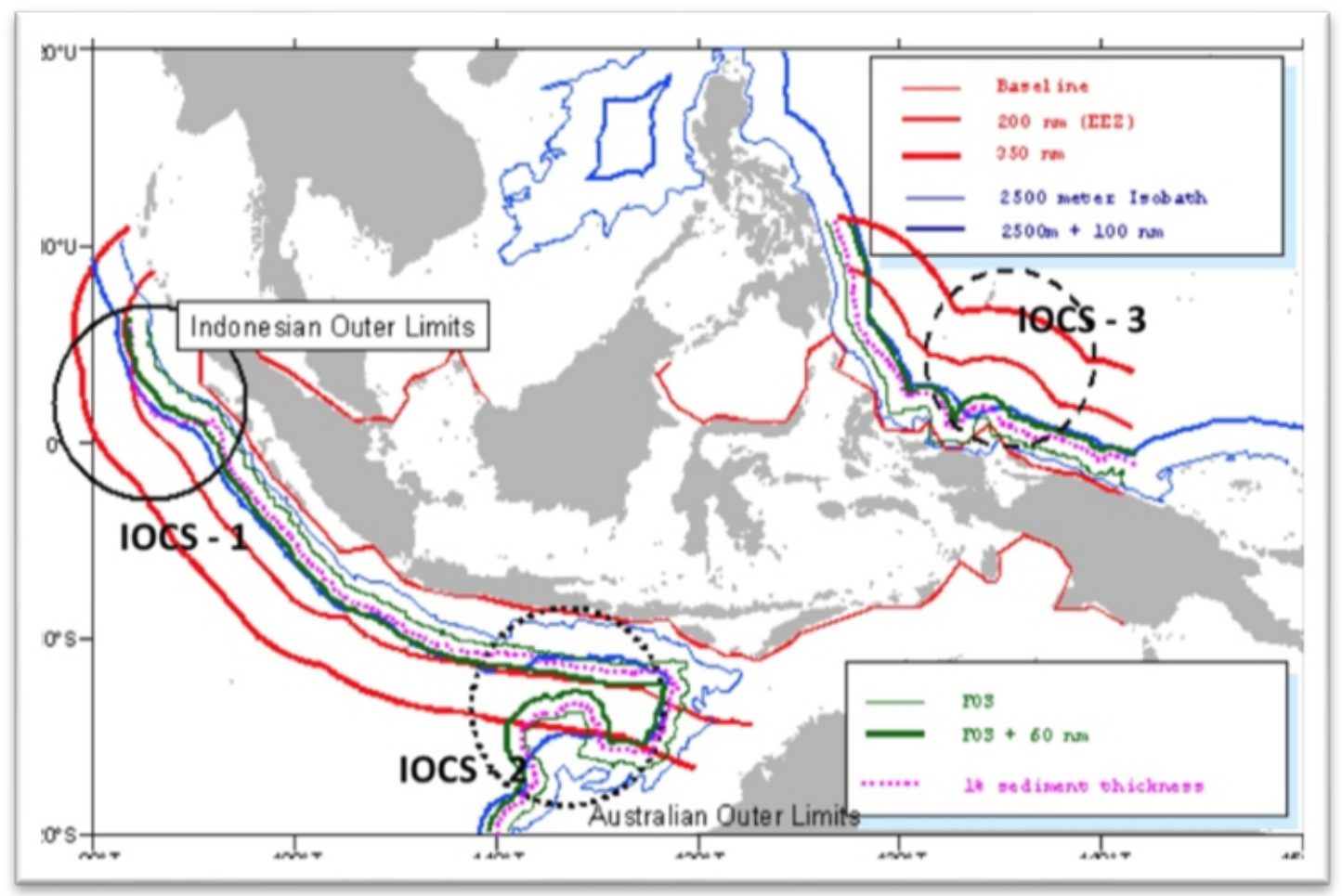

\section{Peraturan Perundang-Undangan Lain Terkait Pemanfaatan Landas Kontinen Indonesia}

Dalam melakukan aktivitas eksploitasi dan eksplorasi di landas kontinen, selain harus berdasarkan UU LKI terdapat pula peraturan perundang-undangan lain yang

61 Prijantono Stjario dan Imelda R. Silalahi, "Tinjauan Geologi Landas Kontinen Indonesia di luar 200 mil laut Sebelah Selatan Perairan Pulau Sumba", Jurnal Geologi Kelautan, Volume 11, Nomor 2, Agustus 2013, hlm 76, http://ejournal.mgi.esdm.go.id/index.php/igk/article/download/232/222, diakses pada 20 Oktober 2016.

62 Yusuf S. Djajadihardja, "Rencana Submisi LKI Utara Papua, Selatan NTT dan Selatan Jawa", disampaikan pada Rapat Koordinasi Pembahasan Submisi Landas Kontinen Indonesia, Kementrian Koordinator Bidang Kemaritiman, Bandung, 21 September 2016.

63 Ibid.

64 Prijantono Stjario dan Imelda R. Silalahi, Op.cit., hlm 68. 
terkait, antara lain wilayah negara, kelautan, pertahanan dan keamanan nasional, pertambangan, dan perhubungan laut. Berikut adalah pemaparan dari berbagai peraturan perundang-undangan yang dimaksud:

\section{a. Wilayah Negara}

Sebagai realisasi amanat Pasal 25 UUD 1945, UU Wilayah Negara dikeluarkan dalam rangka memberikan kepastian hukum dan kejelasan kepada warga negara mengenai wilayah negara yang meliputi wilayah daratan, perairan pedalaman, perairan kepulauan dan laut teritorial beserta dasar laut, dan tanah dibawahnya, serta ruang udara diatasnya, termasuk seluruh sumber kekayaan yang terkandung didalamnya. Dalam UU Wilayah Negara dijelaskan bahwa landas kontinen merupakan wilayah yurisdiksi, yaitu wilayah yang berada di luar wilayah negara, di mana negara memiliki hak-hak berdaulat dan kewenangan tertentu lainnya sebagaimana diatur dalam peraturan perundang-undangan dan hukum internasional. ${ }^{65}$

Sementara pengertian landas kontinen Indonesia meliputi dasar laut dan tanah di bawahnya dari area di bawah permukaan laut yang terletak di luar laut teritorial, sepanjang kelanjutan alamiah wilayah daratan hingga pinggiran luar tepi kontinen, atau hingga suatu jarak 200 mil laut dari garis pangkal dari mana lebar laut teritorial diukur, dalam hal pinggiran luar tepi kontinen tidak mencapai jarak tersebut, hingga paling jauh 350 mil laut sampai dengan jarak 100 (seratus) mil laut dari garis kedalaman 2.500 meter. $^{66} \mathrm{UU}$ ini telah mengadopsi kriteria batas terluar landas kontinen berdasarkan KHL 1982.

\section{b. Kelautan}

Pengaturan mengenai kelautan ini tergolong baru, memiliki lingkup pengaturan yang sangat luas dan komprehensif, yaitu UU Kelautan. Dasar pembentukan UU ini adalah pengaturan wilayah laut Indonesia yang memiliki posisi dan nilai strategis dari berbagai aspek mencakup politik, ekonomi, sosial budaya, pertahanan, dan keamanan yang menjadi dasar pembangunan nasional, serta pengelolaan sumber daya kelautan yang dilakukan melalui kerangka hukum dalam memberikan kepastian hukum dan bermanfaat bagi seluruh masyarakat.

Berdasarkan UU Kelautan, pengertian sumber daya kelautan adalah sumber yang dapat diperbaharui maupun yang tidak dapat diperbaharui yang memiliki keunggulan komparatif dan kompetitif serta dapat dipertahankan dalam jangka panjang. ${ }^{67}$ Penyelenggaraan kelautan dalam hal pemanfaatan sumber daya kelautan atau kegiatan di wilayah laut harus sesuai dengan ketentuan peraturan perundang-undangan dan hukum internasional, serta harus memberikan

\footnotetext{
Pasal 1 huruf 3 Undang-Undang Nomor 43 Tahun 2008 tentang Wilayah Negara (UU Wilayah Negara)..

Pasal 1 huruf 9 UU Wilayah Negara.

Pasal 1 ayat (7) Undang-Undang Nomor 32 Tahun 2014 tentang Kelautan (UU Kelautan).
} 
kepastian hukum serta manfaat bagi seluruh masyarakat. ${ }^{68} \mathrm{UU}$ ini menyatakan wilayah yang termasuk yurisdiksi Indonesia adalah Zona Tambahan, ZEE, dan Landas Kontinen, serta memiliki hak berdaulat di ZEE serta di Landas Kontinen. ${ }^{69}$

Satu hal yang menarik, UU ini mengatur mengenai hak Indonesia dalam melakukan klaim Landas Kontinen di luar 200 mil laut, dan pengajuannya-yaitu disampaikan kepada Komisi Batas-Batas Landas Kontinen PBB-sebelum ditetapkan sebagai landas kontinen Indonesia oleh pemerintah. ${ }^{70}$ Landas kontinen di luar 200 mil laut yang telah mendapatkan persetujuan komisi selanjutnya harus dikelola berdasarkan ketentuan peraturan perundang-undangan dan hukum laut internasional. ${ }^{71}$

UU Kelautan juga mengatur kewenangan pengelolaan kelautan bagi pemerintah dan pemerintah daerah terkait pemanfaatan sumber daya kelautan energi dan sumber daya mineral, ${ }^{72}$ termasuk sumber daya perikanan di wilayah laut yurisdiksi. ${ }^{73}$ Selanjutnya, pengaturan mengenai pemanfaatan sumber daya mineral serta pemanfaatan energi terbarukan yang berasal dari laut harus dilakukan sesuai dengan peraturan perundang-undangan dan hukum internasional. ${ }^{74}$

UU Kelautan turut mengatur mengenai bangunan laut (instalasi di laut) yang tidak mengganggu alur pelayaran maupun Alur Laut Kepulauan Indonesia (ALKI) serta memperkatikan daerah keselamatan (safety zones). ${ }^{75}$ Selain itu, UU Kelautan juga mengatur mengenai riset ilmu pengetahuan dan teknologi kelautan yang terintegrasi dengan sistem nasional penelitian pengembangan penerapan teknologi yang difasilitasi oleh pemerintah, antara lain perizinan dan pelaksanaan riset ilmiah dengan pihak asing. ${ }^{76} \mathrm{UU}$ Kelautan mencakup pula pengaturan terkait pertahanan, keamanan, serta penegakan hukum di laut. ${ }^{77}$

\section{c. Pertahanan dan Keamanan Nasional}

Peraturan perundang-undangan terkait pertahanan dan keamanan nasional merujuk pada Undang-Undang Nomor 3 Tahun 2002 tentang Pertahanan Negara (UU Pertahanan Negara). ${ }^{78}$ UU Pertahanan Negara menyatakan sumber daya alam sebagai bagian dari sistem pertahanan negara. Sumber daya alam yang dimaksud

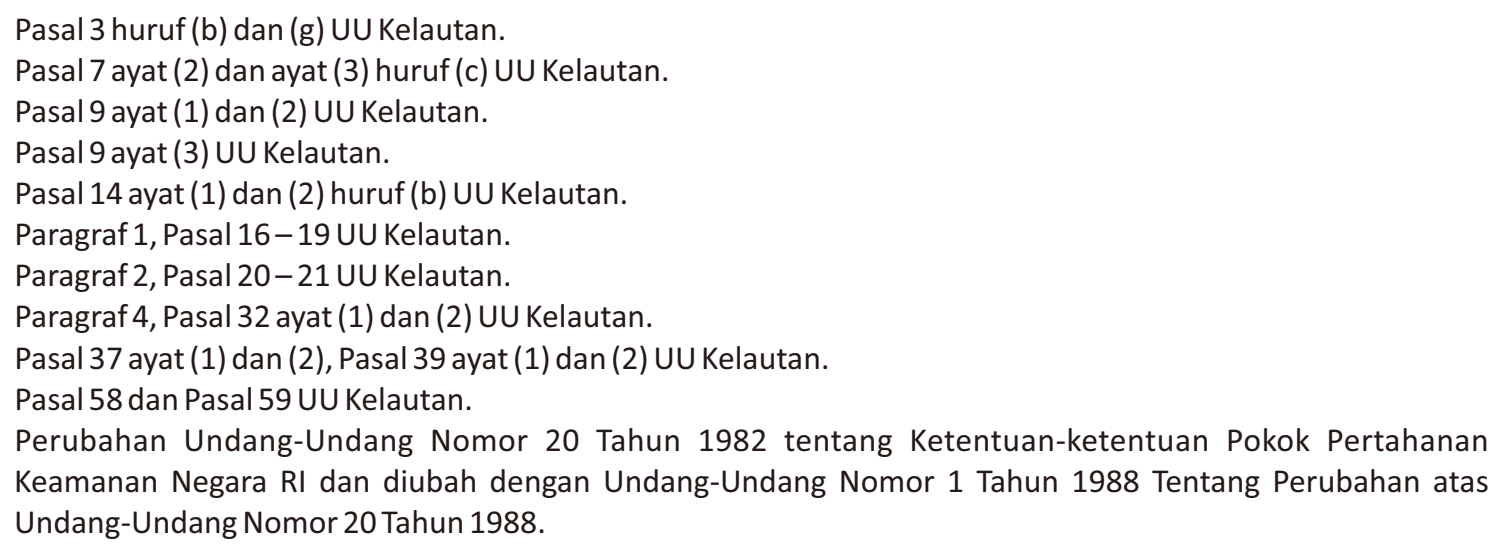


terdapat di dalam ketentuan Pasal 1 ayat (9) menyatakan: "Sumber daya alam adalah potensi yang terkandung dalam bumi, air, dan dirgantara yang dalam wujud asalnya dapat didayagunakan untuk kepentingan pertahanan negara". Dalam Rancangan Undang-Undang (RUU) tentang Keamanan Nasional, Pasal 1 ayat (3) disebutkan mengenai sistem keamanan nasional, meskipun terminologi yang digunakan dalam merujuk sumber daya alam adalah sumber daya nasional.

\section{d. Pertambangan}

Peraturan dalam hal tambang terdapat dalam Undang-Undang Nomor 4 Tahun 2009 tentang Pertambangan Mineral dan Batubara (UU Minerba). ${ }^{79}$ Berdasarkan UU ini, mineral dan batubara yang berada di wilayah Indonesia merupakan sumber daya alam tak terbarukan dan memiliki peranan penting bagi perekonomian negara. UU Minerba tidak mengatur secara khusus kegiatan pertambangan mineral di wilayah laut Indonesia. Pasal yang berkaitan dengan pertambangan di laut terdapat di dalam ketentuan Pasal 6 ayat (1) huruf (f), (g), dan (h) yaitu mengenai kewenangan pemerintah dalam pemberian Izin Usaha Pertambangan (IUP) di mana usaha pertambangan, lokasi pertambangan, dan operasi produksi pertambangannya berada pada wilayah laut lebih dari 12 (dua belas) mil laut dari garis pantai. ${ }^{80}$

Peraturan perundang-undangan lain adalah Peraturan Pemerintah Nomor 22 Tahun 2010 tentang Wilayah Pertambangan (PP 22/2010)..$^{81}$ Dalam ketentuan Pasal 2 ayat (1) disebutkan bahwa wilayah pertambangan (WP) merupakan kawasan yang memiliki potensial mineral dan/atau batubara yang berada di permukaan tanah maupun di bawah tanah, baik di wilayah darat atau di wilayah laut. PP 22/2010 pada dasarnya mengatur mengenai pembagian wewenang, misalnya dalam kegiatan penyelidikan dan penelitian pertambangan untuk memperoleh data dan informasi, maka menteri berwenang melakukan penyelidikan dan wilayah laut dengan jarak 12 mil laut dari garis pantai atau yang berbatasan dengan negara lain, gubernur untuk wilayah laut dengan jarak 4-12 mil laut dari garis pantai, dan bupati untuk wilayah laut sampai dengan 4 mil laut dari garis pantai. ${ }^{82}$

"Kewenangan Pemerintah dalam pengelolaan pertambangan mineral dan batubara, antara lain, adalah: ... (f) pemberian IUP, pembinaan, penyelesaian konflik masyarakat, dan pengawasan usaha pertambangan yang berada pada lintas wilayah provinsi dan/atau wilayah laut lebih dari 12 (dua belas) mil dari garis pantai; (g) pemberian IUP, pembinaan, penyelesaian konflik masyarakat, dan pengawasan usaha pertambangan yang lokasi penambangannya berada pada lintas wilayah provinsi dan/atau wilayah laut lebih dari 12 (dua belas) mil dari garis pantai; (h) pemberian IUP, pembinaan, penyelesaian konflik masyarakat, dan pengawasan usaha pertambangan operasi produksi yang berdampak lingkungan langsung lintas provinsi dan/atau dalam wilayah laut lebih dari 12 (dua belas) mil dari garis pantai ...".

81 Peraturan Pemerintah (PP) ini merupakan peraturan pelaksana berdasarkan Pasal 89 Undang-Undang Nomor 4 Tahun 2009 tentang Pertambangan Mineral dan Batubara (UU Minerba).

82 Pasal 6 ayat (1) huruf (a), (b), dan (c) Peraturan Pemerintah Nomor 22 Tahun 2010 tentang Wilayah Pertambangan (PP 22/2010). 
Pembagian wewenang tersebut juga diatur terkait penetapan Wilayah Izin Usaha Pertambangan (WIUP) dengan wilayah laut dengan jarak yang sama. ${ }^{83}$ Peraturan lainnya terdapat di dalam Peraturan Pemerintah Nomor 23 Tahun 2010 tentang Pelaksanaan Kegiatan Usaha Pertambangan Mineral dan Batubara (PP 23/2010). ${ }^{84}$ Pada dasarnya, PP 23/2010 ini mengatur mengenai pembagian wewenang antara menteri (ESDM), gubernur, dan bupati terkait dengan pelaksanaan wewenang pelelangan WIUP, ${ }^{85}$ permohonan WIUP, ${ }^{86}$ IUP Eksplorasi, ${ }^{87}$ dan IUP Operasi Produksi. ${ }^{88}$

\section{e. Perhubungan Laut}

Peraturan perundang-undangan dalam hal perhubungan laut diatur di dalam Undang-Undang Nomor 17 Tahun 2008 tentang Pelayaran (UU Pelayaran). ${ }^{89}$ UU Pelayaran mengatur keselamatan dan keamanan pelayaran dalam hal navigasi melalui Sarana Bantu Navigasi-Pelayaran dan Telekomunikasi Pelayaran dengan menetapkan zona keamanan dan keselamatan di sekitar instalasi bangunan. ${ }^{90}$ Penetapan zona keamanan di Perairan Indonesia harus ditetapkan dan diumumkan oleh pemerintah. ${ }^{91}$ Setiap kegiatan pembangunan, pemindahan, atau pembongkaran bangunan atau instalasi di laut harus memenuhi persyaratan dan izin daripemerintah. ${ }^{92}$

Pelayaran dan navigasi di perairan Indonesia ditetapkan melalui ALKI dengan memperhatikan ketahanan nasional, keselamatan berlayar, eksplorasi dan eksploitasi sumber daya alam, jaringan kabel dan pipa dasar laut, konservasi sumber daya alam dan lingkungan, rute yang biasanya digunakan untuk pelayaran internasional, tata ruang laut, dan rekomendasi organisasi internasional yang berwenang. ${ }^{93}$ Beberapa undang-undang seperti UU LKI dan Undang-Undang Nomor 5 Tahun 1983 tentang Zona Ekonomi Eksklusif Indonesia (UU ZEE Indonesia) tunduk terhadap ketentuan UU Pelayaran ini sepanjang berkaitan dengan aspek keselamatan dan keamanan pelayaran.

Pasal 22 ayat (2) huruf (a), (b), (c) PP 22/2010.

PP ini merupakan peraturan pelaksana ketentuan Pasal 5 ayat (5), Pasal 34 ayat (3), Pasal 49, Pasal 63, Pasal 65 ayat (2), Pasal 71 ayat (2), Pasal 76 ayat (3), Pasal 84, Pasal 86 ayat (2), Pasal 103 ayat (3), Pasal 109, Pasal 111 ayat (2), Pasal 112, Pasal 116, dan Pasal 156 UU Minerba .

Pasal 11 ayat (1) Peraturan Pemerintah Nomor 23 Tahun 2010 tentang Pelaksanaan Kegiatan Usaha Pertambangan Mineral dan Batubara (PP 23/2010).

Pasal 20 ayat (1) PP 23/2010.

Pasal 28 huruf (a), (b), (c) PP 23/2010.

Pasal 35 ayat (1) huruf (a), (b), (c) PP 23/2010.

Pengganti Undang-Undang Nomor 21 Tahun 1992 tentang Pelayaran (UU Pelayaran).

Pasal 119 ayat (2) UU Pelayaran.

Pasal 195 huruf (a) UU Pelayaran.

Pasal 195 ayat (2) UU Pelayaran.

Pasal 194 ayat (2) UU Pelayaran. 


\section{f. Perikanan}

Pengaturan mengenai perikanan saat ini diatur di dalam Undang-Undang Nomor 45 Tahun 2009 tentang Perubahan atas Undang-Undang Nomor 31 Tahun 2004 tentang Perikanan (UU Perikanan). Lingkup pengaturan pemanfaatan sumber daya ikan yang dimaksud oleh UU ini berlaku di laut teritorial, ZEE Indonesia, dan laut lepas. Tidak terdapat pengaturan terkait jenis sedenter atau organisme hidup lainnya yang biasa ditemukan di landas kontinen. Lebih lanjut diatur di dalam UU Kelautan di mana terdapat pengaturan mengenai sumber daya kelautan terdapat di dalam yaitu sumber daya laut, baik yang dapat diperbaharui maupun tidak dapat diperbaharui yang memiliki keunggulan komparatif dan kompetitif serta dapat dipertahankan dalam jangka panjang. ${ }^{94}$ Pemanfaatan sumber daya kelautan tersebut meliputi perikanan, yang mana pemerintah dan pemerintah daerah memiliki kewenangan untuk melakukan pengelolaan sumber daya perikanan dengan menggunakan prinsip ekonomi biru. ${ }^{95}$

Pengaturan khusus mengenai perikanan terdapat di dalam Bagian Kedua mengenai Pemanfaatan Sumber Daya Kelautan Perikanan. Pengelolaan sumber daya ikan dilakukan di wilayah perairan dan wilayah yurisdiksi dan di laut lepas berdasarkan kerja sama dengan negara lain (Regional Fisheries Management Organizations-RMFOs). ${ }^{96}$ Pemerintah harus melakukan koordinasi pengelolaan sumber daya ikan serta mewujudkan industri perikanan, maka pemerintah bertanggung jawab untuk menjaga kelestarian sumber daya ikan. ${ }^{97}$

\section{g. Perlindungan Lingkungan Laut}

Perlindungan lingkungan laut dilakukan melalui tindakan konservasi laut, pengendalian pencemaran laut, penanggulangan bencana kelautan, dan pencegahan serta penanggulangan pencemaran, perusakan, dan bencana. Pencemaran laut meliputi pencemaran yang berasal dari kegiatan di darat, laut, dan udara di perairan teritorial dan yurisdiksi. ${ }^{98}$ Pemerintah bertanggung jawab atas perlindungan dan pelestarian lingkungan laut yang dilakukan melalui pencegahan, pengurangan, dan pengendalian dari setiap pencemaran, dan untuk mewujudkan hal tersebut, pemerintah dapat melakukan ker jasama (bilateral atau multilateral). ${ }^{99}$ Pelaksanaan perlindungan dan pelestarian lingkungan laut dilaksanakan berdasarkan peraturan perundang-undangan terkait dan hukum internasional. ${ }^{100}$

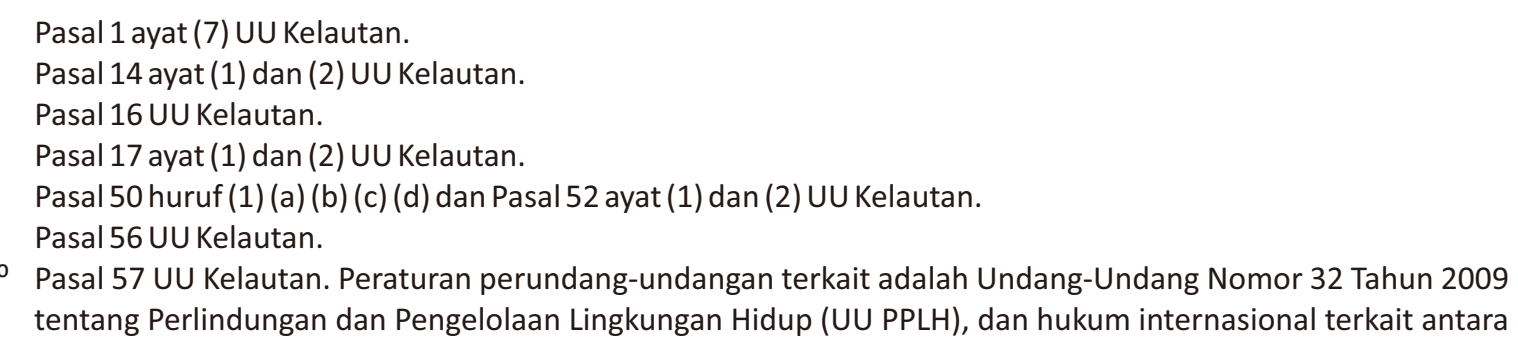




\section{h. Riset IImiah Kelautan}

UU terkait riset ilmiah terdapat di dalam ketentuan Undang-Undang Nomor 18 Tahun 2001 tentang Sistem Nasional, Penelitian, Pengembangan, dan Penerapan Ilmu Pengetahuan dan Teknologi. Peraturan lainnya adalah Peraturan Pemerintah Nomor 41 Tahun 2006 tentang Perizinan Melakukan Kegiatan Penelitian dan Pengembangan Bagi Perguruan Tinggi Asing, Lembaga Penelitian dan Pengembangan Asing, Badan Usaha Asing, dan Orang Asing. Kedua peraturan perundangundang tersebut tidak mengatur secara langsung mengenai riset ilmiah kelautan.

Dalam UU Kelautan, riset ilmu pengetahuan dan teknologi diatur di dalam ketentuan Pasal 37-40. Pemerintah dan pemerintah daerah mengembangkan sistem penelitian pengembangan serta penerapan ilmu pengetahuan dan teknologi kelautan sebagai bagian integral dari sistem nasional penelitian pengembangan penerapan. ${ }^{101}$ Pemerintah memfasilitasi pendanaan, pengadaan, perbaikan, penambahan sarana prasarana, serta perizinan untuk penelitian dan pengembangan ilmu pengetahuan dan teknologi kelautan. ${ }^{102}$ Terkait kerja sama dengan pihak asing, pemerintah mengatur pelaksanaan penelitian ilmiah kelautan tersebut dan hasil penelitiannya wajib disampaikan kepada pemerintah. ${ }^{103}$ Sistem informasi dan data kelautan terkait hasil penelitian ilmiah kelautan berupa data numerik dan analisisnya, hasil penelitian berupa data spasial dan analisisnya, pengelolaan sumber daya kelautan, konservasi perairan, dan pengembangan teknologi kelautan. ${ }^{104}$

\section{Penutup}

Berdasarkan pemaparan di atas, maka dapat diambil kesimpulan bahwa revisi UU LKI yang telah berlaku selama 44 tahun bersifat mendesak berdasarkan alasanalasan sebagai berikut:

1. Ratifikasi Indonesia terhadap KHL 1982 tidak serta merta diikuti dengan revisi terhadap UU LKI yang masih mengacu pada Konvensi LK. Padahal terdapat perbedaan yang signifikan terkait penetapan batas terluar landas kontinen berdasarkan Konvensi LK (menggunakan kriteria kedalaman dan 'exploitability') dengan KHL 1982, yakni kriteria dalam menentukan pinggiran terluar tepi kontinen atau kriteria jarak 200 mil laut dari garis pangkal. Selanjutnya, KHL 1982 juga memperbolehkan negara untuk mengajukan perpanjangan landas

\footnotetext{
lain Bab XII KHL 1982 (Pasal 192-211), the International Convention for the Prevention of Pollution from Ships 1973 as modified by the Protocol of 1978 (MARPOL 73/78), dan Montreal Guidelines for the Protection of the Marine Environment against Pollution from Land-Based Sources 1985 (Montreal Guidelines 1985).

101 Pasal 37 ayat (1) UU Kelautan.

102 Pasal 37 ayat (2) UU Kelautan.

103 Pasal 39 ayat (1) dan (2) UU Kelautan.

104 Pasal 40 ayat (2) UU Kelautan.
} 
kontinen dengan terlebih dahulu memenuhi syarat yang terdapat dalam Pasal 76 KHL 1982. Ketentuan dalam KHL 1982 tersebut dinilai lebih mudah untuk diaplikasikan mengingat perbedaan kondisi geologis dan topografi landas kontinen, serta lebih menguntungkan bagi negara-negara pantai. Konteks tersebut seharusnya mendorong pemerintah untuk segera melakukan revisi UU LKI.

2. Praktik Indonesia dalam mengajukan perpanjangan landas kontinen di luar 200 mil laut pada tahun 2008 merupakan langkah besar sebagai wujud pemanfaatan hak berdasarkan KHL 1982. Disetujuinya perpanjangan landas kontinen di daerah barat laut Sumatera oleh Komisi Batas-Batas Landas Kontinen PBB serta rencana pengajuan submisi lainnya merupakan salah satu faktor mengapa diperlukan revisi UU LKI, karena perkembangan tersebut harus disertai dengan diberlakukannya peraturan perundang-undangan yang lebih relevan dengan kondisi saat ini.

3. Pada tahun 2008 Pemerintah mengeluarkan UU Wilayah Negara dan pada tahun 2014 mengeluarkan UU Kelautan yang didalamnya terdapat pengaturan terkait penetapan batas terluar landas kontinen serta perpanjangan landas kontinen di luar 200 mil laut. Apabila dikaitkan dengan daya laku dan daya guna suatu peraturan perundang-undangan, maka ketentuan penetapan batas terluar landas kontinen berdasarkan UU LKI sudah tidak berdayaguna meskipun masih berlaku karena tidak pernah dicabut. UU LKI merupakan undang-undang yang bersifat khusus, di mana seluruh isi pasal-pasalnya mengatur mengenai pemanfaatan landas kontinen; sementara UU Wilayah Negara dan UU Kelautan bersifat umum, karena pengaturan landas kontinen hanya menjadi salah satu aspek yang diatur dalam UU tersebut. UU LKI berlaku lebih dulu dibanding kedua UU yang lahir belakangan, namun ketiga peraturan perundang-undangan tersebut memiliki tingkatan yang sama (berbetuk UU). Persoalan muncul ketika terdapat perbedaan substansial dalam penetapan batas terluar landas kontinen. Guna mengakhiri polemik tersebut, revisi UU LKI harus secepatnya terwujud demi tercipta kepastian dan ketertiban hukum.

\section{Daftar Pustaka}

\section{Buku}

C.S.T Kansil dan Christine S.T. Kansil, Pengantar IImu Hukum Indonesia, Rineka Cipta, Jakarta, 2014.

Churchill, R.R dan A.V. Lowe, The law of the Sea, $3^{\text {rd }}$ Edition, Juris Publishing and Manchester University Press, Manchester, UK, 1999.

I Wayan Parthiana, Hukum Laut Internasional dan Hukum Laut Indonesia, Penerbit Yrama Widya, Bandung, 2014. 
Mochtar Kusumaatmadja, Hukum Laut Internasional, Binacipta, Bandung, 1986.

Oda, Shigeru, International Law of the Resources of the Sea, Sijthoff and Noordhoff International Publishers BV Alphen aan de Rijn, the Netherlands, 1979.

Rothwell, Donald R. dan Tim Stephens, The International Law of the Sea, Hart Publishing, Oxford and Portland, Oregon, 2010.

Sohn, Louis B. dan Kristen Gustafson, The Law of the Sea in a Nutshell, West Publishing Company, St. Paul, Minnesota, 1993.

Tanaka, Yoshifumi, The International Law of the Sea, Cambridge University Press, Cambridge, 2012.

\section{Dokumen Lain}

Garry Gumelar Pratama, "Konflik versus Kooperasi: Upaya Penyelesaian Sengketa Laut Tiongkok Selatan dan Integrasi ASEAN ke Iklim Ekonomi Global", Padjadjaran Jurnal Ilmu Hukum, Vol. 3 No. 1, 2016.

Khafid, "Pengalaman melakukan parsial submisi Landas Kontinen Indonesia di luar 200 mil laut di sebelah barat laut Sumatera untuk mendukung penyusunan Rancangan Undang-Undang Landas Kontinen Indonesia", disampaikan dalam kegiatan Sosialisasi RUU tentang Landas Kontinen Indonesia, Selasa, 26 April 2011, Jakarta, http://ditjenpp.kemenkumham.go.id/files/doc/1276 khafid\% 20\%20Pengalaman\%20Submisi\%20LKI\%20untuk\%20mendukung\%20RUU\%2 OLandas\%20Kontinen.pdf, diakses pada 20 Oktober 2016.

Perserikatan Bangsa-Bangsa, "Submissions, through the Secretary-General of the United Nations, to the Commissions on the Limits of the Continental Shelf, pursuant to article 76, paragraph 8, of the United Nations Convention on the Law of the Sea of 10 December 1982", http://www.un.org/depts/los/clcs new/commission submissions.htm diakses pada 24 Oktober 2016.

"Summary of Recommendations of the Commission of the Limits of the Continental Shelf in regard to the submission made by Indonesia in respect of the area north west of Sumatera on 16 June 2008", http://www.un.org/depts/los/clcs new/submissions files/idn08/

Summary\%20Recommendations\%20for\%20Indonesia.pdf, diakses pada 22 Oktober 2016.

Prijantono Stjario dan Imelda R. Silalahi, "Tinjauan Geologi Landas Kontinen Indonesia di luar 200 mil laut Sebelah Selatan Perairan Pulau Sumba", Jurnal Geologi Kelautan, Volume 11, Nomor 2, Agustus 2013, http://ejournal.mgi. esdm.go.id/index.php/jgk/article/download/232/222, diakses pada 20 Oktober 2016.

Sobar Sutisna dan Sora Lokita, "Indonesia First Experiences in Delineating Extended Continental Shelf to the UN-CLCS", Indonesian J. Int'I L. 682 (2010-2011), Vol. 8 No. 4, Juli 2011, http://heinonline.org/HOL/LandingPage? 
handle=hein.journals/indjil8\&div=53\&id=\&page diakses pada 24 Oktober 2016.

Suparman Diraputera, (et. al.), "Naskah Akademik RUU Undang-Undang No. 1 Tahun 1974 tentang Landas Kontinen Indonesia", http://www.bphn.go.id/ data/documents/naskah_akademik_ruu_tentang_landas_kontinen_indonesi a.pdf, diakses pada 26 Oktober 2016.

Yusuf S. Djajadihardja, "Rencana submisi LKI Utara Papua, Selatan NTT dan Selatan Jawa", disampaikan pada Rakor Pembahasan Submisi Landas Kontinen Indonesia, Kementrian Koordinator Bidang Kemaritiman, Bandung, 21 September 2016.

\section{Dokumen Hukum}

Konvensi Jenewa tentang Landas Kontinen 1958.

Konvensi Hukum Laut 1982.

Undang-Undang Nomor 1 Tahun 1973 tentang Landas Kontinen Indonesia.

Undang-Undang Nomor 3 Tahun 2002 tentang Pertahanan Negara.

Undang-Undang Nomor 43 Tahun 2008 tentang Wilayah Negara.

Undang-Undang Nomor 4 Tahun 2009 tentang Pertambangan Mineral dan Batubara.

Undang-Undang Nomor 17 Tahun 2008 tentang Pelayaran.

Undang-Undang Nomor 43 Tahun 2008 tentang Wilayah Negara.

Undang-Undang Nomor 4 Tahun 2009 tentang Pertambangan Mineral dan Batubara.

Undang-Undang Nomor 32 Tahun 2014 tentang Kelautan.

Peraturan Pemerintah Nomor 22 Tahun 2010 tentang Wilayah Pertambangan.

Peraturan Pemerintah Nomor 23 Tahun 2010 tentang Pelaksanaan Kegiatan Usaha

Pertambangan Mineral dan Batubara. 